\title{
DEVELOPMENT OF ROMA SETTLEMENTS IN NORTHERN MOLDOVA AROUND HUBS AND INTERCHANGES
}

DOI: http://dx.doi.org/10.18509/GBP.2017.33

UDC: 911.375.64:728-054(=214.58:478)

\section{Vasile Efros}

Ionela Gălbău

Stefan cel Mare University of Suceava, Faculty of History and Geography, Department of Geography, Universitatii 1, Suceava, Romania

\begin{abstract}
The commercial roads, which have linked Northern Moldavia to the other regions of the country ever since the Middle Ages, have remained, up until now, intensely distributed and at the base of the economic development of the localities which they throughout. With the exchange of goods which are to be carried out in trade fairs located at the intersection of these roads, traders also transport the Roma ethnic slaves which, after the liberation of the year 1844, have settled in these areas.

The region of study is within the region of the north-east of Romania and includes the counties of Iasi, Botosani, Suceava and Neamt. The research was focused on the analysis of statistical data obtained from the National Institute of Statistics, local councils, county centers for the Roma, the National Company of Highways and National Roads from Romania and the Romanian railway and the collection of information on the ground by questioning Roma people from the pilot localities Pascani, Dolhasca, Dorohoi and Veresti The research has revealed a large concentration of the number of Roma settlements at the intersection with the main road railways. Compared with Roma in other localities in the study area who do not have these transport facilities, the proportions of Roma communities from Paşcani, Dolhasca, Vereşti, Dorohoi, Iasi, Suceava and Roman represent over $10 \%$ of the population stable. Opportunities due to development of transport networks in northern Moldavia does not only reflect on the growth of the Roma population density but also on the economic development of the area.
\end{abstract}

Keywords: Roma communities, transport facilities, transport networks

\section{INTRODUCTION}

The period of the Middle Ages was one favorable to the economic development of the Moldova Region, thanks to a large extent, evolving network of roads to trade and of cities fairs. The most important commercial corridor of the Moldova Region was represented by the way that link the Kiev city to the Black Sea and to the Romanian States.

All this period of the Middle Ages, meant for the Roma the page of their history because of the bondage to which they have been subjected. Trade fairs in Northern Moldavia (Iasi, Pascani, Suceava, Roman) were real markets that made the trade with the Roma menservants and the animals or money [3]. The first documentary attestation with regard to the Roma people from the north of Moldavia dates from 8 July 1428, when 31 of dwellings Roma were donated by the ruler Alexandru cel Bun to the Bistrita Monastery [4]. Therefore, the Roma were considered slaves, either of the ruler or to the nobles. The fact that they were imprisoned in the stables of animals and fed in line with those, 
determined the Roma people to accept slavery in order to receive the dwellings and to be raise in line with people.

On 14 February 1844, is voted the law under which sedentary and nomads slaves became free, with the same rights as other inhabitants of the country. Releasing of Roma people from bondage in this year, was a first social reform in relation to the situation of the Roma, that period which lasted approximately 20 years [1] and in which they were laid the foundations of the railway transport.

The evolution of the railways and the development of the road, throughout history, have been the most powerful elements of the initiators of economic development [7] both by reducing the cost of transport, but especially in the development of new areas of production and sales outlet. In respect to the influence of transport networks to the geographical distribution of the population, recent studies emphasize the connection between the demographic evolution and the evolution of the transport roads [6]. The relationship between the network of railways and road, on the one hand, and demographic trends or ethnic origin of a localities, is extremely dynamic and has evolved along decades [2].

One of the objectives of this work is to reveal the relationship between the transport networks (road and rail) and geodemographical evolution of the localities transited for them in the region of the North-East of Romania.

\section{MATERIALS AND METHODS}

The present research is part of a larger study on the issues of historical and geographical Roma in northern Moldova will be dealt with issues related to migration, the first historic record, exile, deportation, settlement and establishment in the present localities as such and some demographics.

The region of study is located in the North-East of Romania and includes the counties of Botosani, Iasi, Suceava and Neamt.

The pilot localities identified for research constitute the human settlements crossed by the most important nodes road and railway in the region, while being at the same time, populated by some of the most numerous Roma communities in Northern Moldavia (Roman-1549 Roma people, Iasi-1376 Roma people, Dolhasca -1258 Roma people).

The localities in question are both in the category of the rural areas (Veresti) as well as the urban areas (Pascani, Roman, Dorohoi, Iasi, Suceava, Dolhasca). They are included in the target group due to the fact that are crossed in both the road of European significance (E 58 and E 85) or national (15D, DN17, DN2, DN 22A, DN 22B DN 22D) and two of the largest railway lines in Romania (CFR 500 and CFR 600).

The statistical data used have been obtained from the National Institute of Statistics of Romania and of the work of land, introduced into the statistical program and analyzed using Microsoft Office/Excell. Maps have been obtained using GIS (Geographical Informational Sistem) using information from Domestic Transport by Rail Company (Compania Nationala de Transport Ferovia-CFR), the National Company for the Management of Road Infrastructure (Compania Nationala de Administrare a Infrastructurii Rutiere-CNADR) and the data in the field.

\section{MAIN RESULTS AND DISCUSSIONS}

In the last 50 years the number of Roma people from the localities to analysis has increased substantially, touching the proportions of up to $10 \%$ of the total stable population. 
Table 1. The evolution of the Roma population percentage in the localities analyzed during the period 1966-2014

\begin{tabular}{|c|c|c|c|c|c|c|c|c|c|c|c|}
\hline \multicolumn{4}{|c|}{1966} & \multicolumn{4}{|c|}{2002} & \multicolumn{4}{|c|}{2014} \\
\hline Locality & $\begin{array}{c}\text { Total } \\
\text { number of } \\
\text { population }\end{array}$ & $\begin{array}{c}\text { The } \\
\text { number } \\
\text { of } \\
\text { Roma } \\
\text { people }\end{array}$ & Percent & Locality & $\begin{array}{c}\text { Total } \\
\text { number of } \\
\text { population }\end{array}$ & $\begin{array}{c}\text { The } \\
\text { number } \\
\text { of } \\
\text { Roma } \\
\text { people }\end{array}$ & Percent & Locality & $\begin{array}{c}\text { Total } \\
\text { number of } \\
\text { population }\end{array}$ & $\begin{array}{c}\text { The } \\
\text { number } \\
\text { of } \\
\text { Roma } \\
\text { people }\end{array}$ & Percent \\
\hline Veresti & 6289 & 659 & $10.48 \%$ & Veresti & 7109 & 491 & $6.91 \%$ & Veresti & 3850 & 198 & $5.14 \%$ \\
\hline Dolhasca & 10298 & 1258 & $12.22 \%$ & Dolhasca & 11009 & 1104 & $10.03 \%$ & Dolhasca & 6250 & 325 & $5.20 \%$ \\
\hline Dorohoi & 24309 & 375 & $1.54 \%$ & Dorohoi & 30949 & 451 & $1.04 \%$ & Dorohoi & 16699 & 173 & $1.04 \%$ \\
\hline Pascani & 33745 & 500 & $1.48 \%$ & Pascani & 42057 & 439 & $1.04 \%$ & Pascani & 18689 & 194 & $1.04 \%$ \\
\hline Roman & 50713 & 1549 & $3.05 \%$ & Roman & 69268 & 1594 & $2.90 \%$ & Roman & 39012 & 1131 & $2.90 \%$ \\
\hline Suceava & 92121 & 585 & $0.64 \%$ & Suceava & 105865 & 509 & $0.48 \%$ & Suceava & 37697 & 509 & $1.35 \%$ \\
\hline Iasi & 290422 & 1376 & $0.47 \%$ & Iasi & 320888 & 1898 & $0.59 \%$ & Iasi & 161023 & 950 & $0.59 \%$ \\
\hline
\end{tabular}

You can see a significant increase in the total number of inhabitants in the case of each localities from 1966 until the year 2012. This numerical evolution shall be identified and in the case of the Roma minority. Starting this year by the year 2014, the total number of people is declining.

Equally decreases and the number of inhabitants of Roma from Dorohoi, Roman and Iasi but part of the minorities in the total population from Veresti, Dolhasca, Dorohoi, Roman and Suceava is on the rise by the weights between $0,15 \%$ (Roman) up to $3.57 \%$ (Veresti). By analysing the case of each localities in the counties of Botosani, Iasi, Suceava and Neamt, we noticed higher cores f Roma communities in areas close to main rail lines (CFR 500: Bucharest (North) - Ploiesti (South) - Roman - Pascani - Suceava - Vicsani, CFR 600: Bucuresti-Faurei-Tecuci - Barlad - Crasna Vaslui - Iasi - Ungheni).

Thus, in the analyzed area, can be identified 22 localities with more then 100 in the area of Line 500 and its ramifications (main railways) and 8 localities in the area of Line 600 and ramifications.

The same situation can be observed in the case of the Romani communities near the roads of national importance (15D, DN17, DN2, DN 22A, DN 22B DN 22D) and European highways (E58, E85).

Thus, from the total of the 66 localities in the north of Moldavia, in which the number of Roma people is over 100 persons, 19 are crossed by the European highways E85 and E58 and 20 localities crossed by the national roads.

To determine the influence of road and railway infrastructure on the development of Roma communities, I superimposed the two maps thus obtaining a map of the road network and railway crossing places with very large number of Roma population (over 300 people).

We see a greater concentration of the Roma population in localities which are crossed by important communication means in terms of nationally and internationally. In some of those towns the Roma number exceeds 1200 (Dolhasca - 1258 - 12.22\%, Iasi - 1376 $0.47 \%$, Roman - $1549-3.05 \%$ ).

We consider that the transport infrastructure has been edifying element which has been the basis for sedentarisation of Roma in these localities. Known as members of a nomadic populations, themselves nomads, the Roma people have settled in the areas which they have offered the best means of survival. 


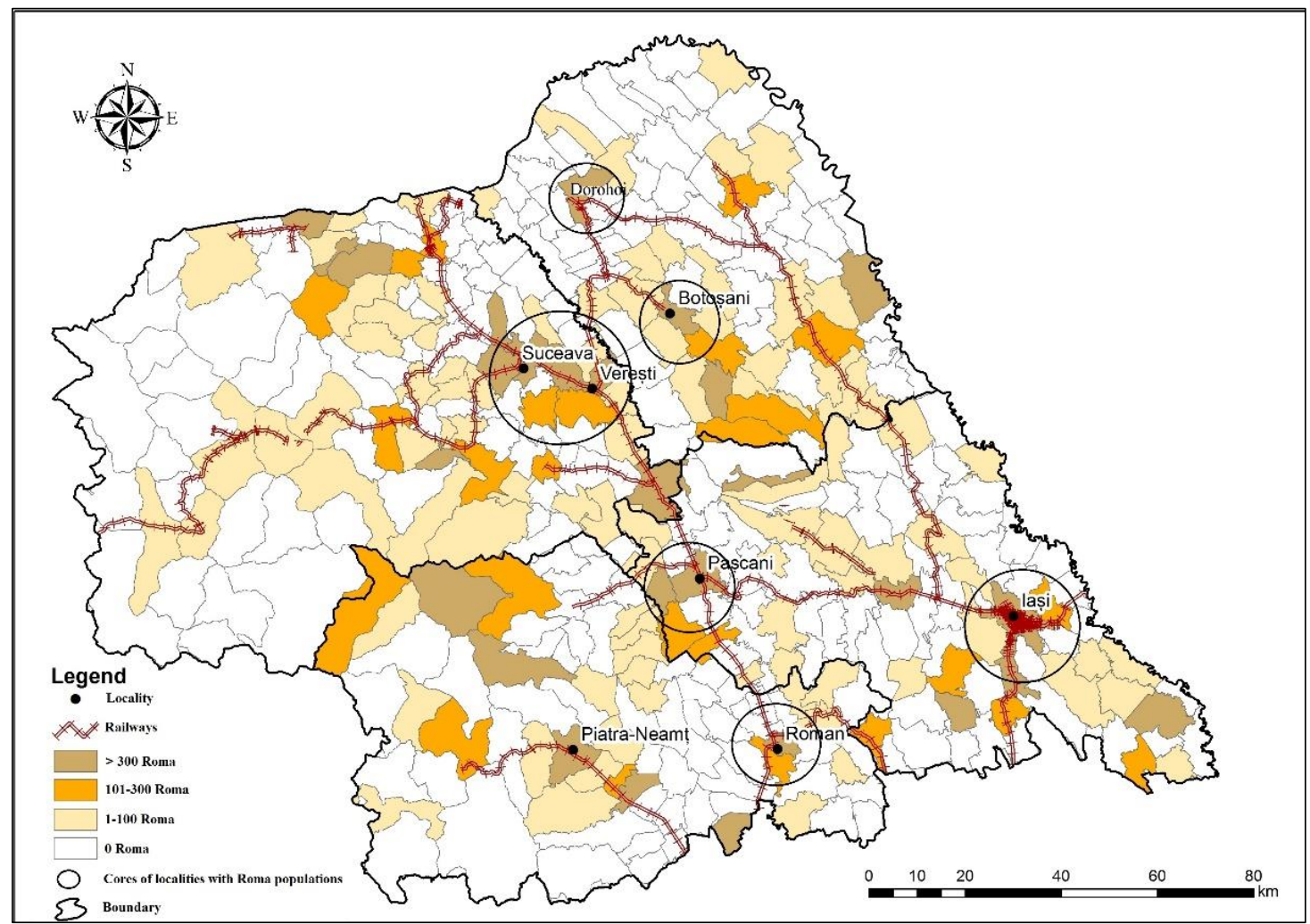

Figure 2. Concentration of roma population in the north of Moldavia and the network of railways

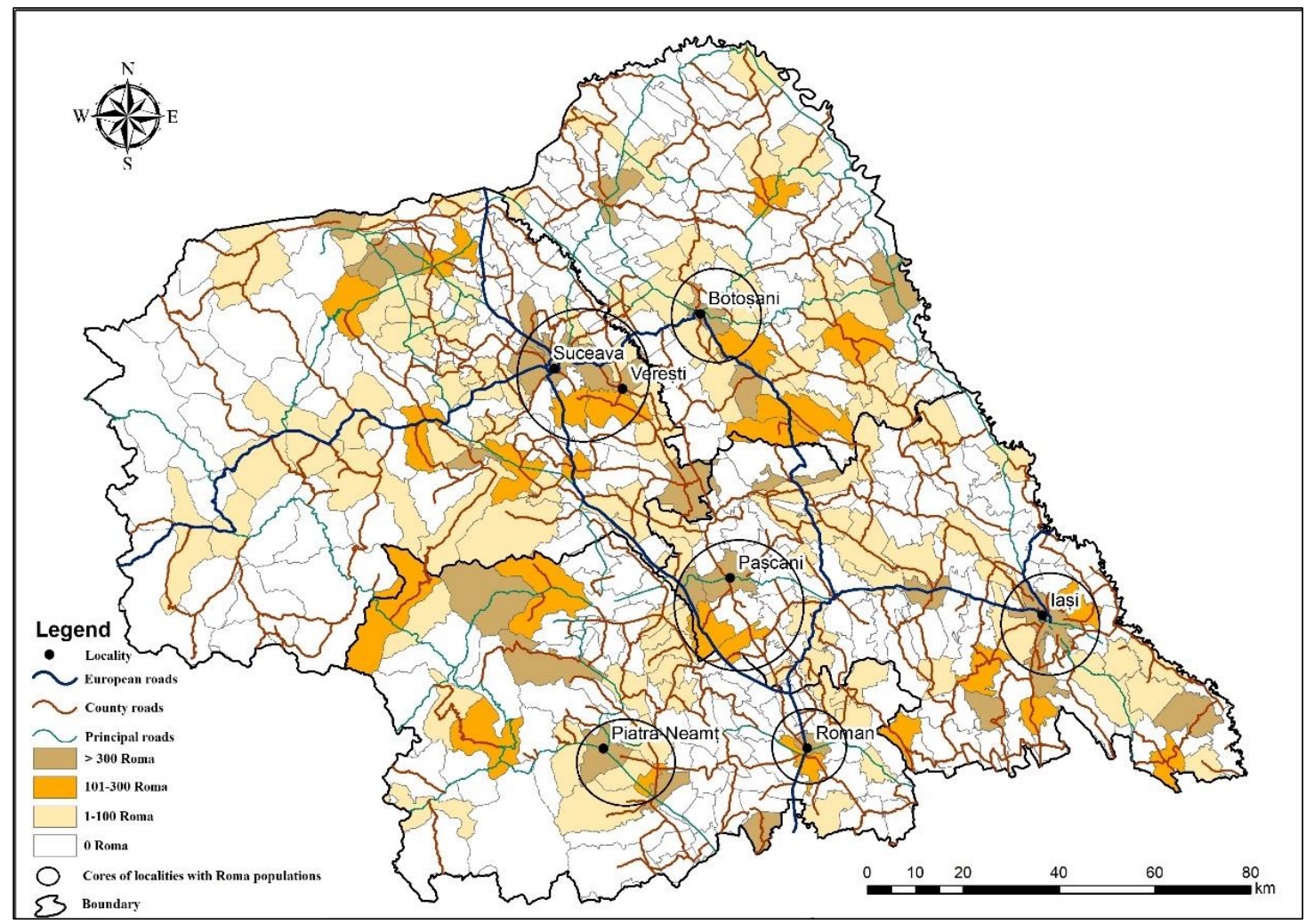

Figure 3. Concentration of roma population and the road 


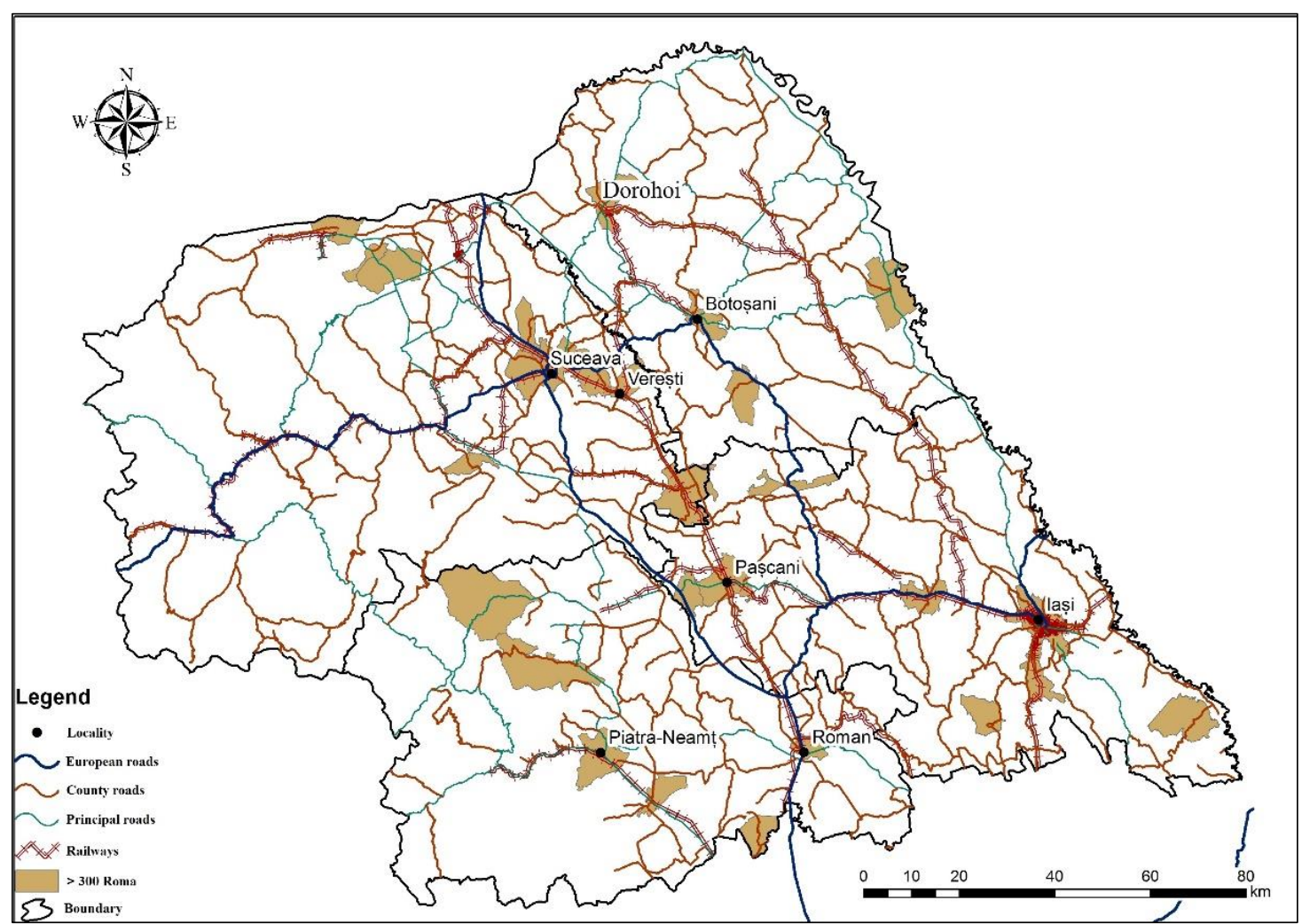

Figure 4. Road and railway infrastructure superimposed on the distribution of Roma in the territory

Due to the trade clandestinely practiced by them in recent decades, the ability to access more easily a means of transport to the large fairs, determined to give up the old traditions and habits (internal migration over short distances, housing in makeshift tents) and align among locals majority.

\section{CONCLUSIONS}

For the majority society, history will always represent a starting point for analyzing the newly established ethnic communities in some areas. Although history was not gentle with them, the Roma are still trying to remove the black mark placed on their social environment and the way in which the social environment concerns..

The members of the Roma ethnic minority in the region of the North-East Romania constitutes a large ethnic community who are trying to integrate into society, both by sedentarizare and by the activities they are involved in. The most important factor which has been the basis for this phenomenon has been the degree of economic development of the localities and the main factor that influenced this degree of development was the railway and road infrastructure.

However this type of infrastructure is not developed at the maximum capacities in the north of Moldavia and any extension of the rail and road networks would be likely to lead to an increase in the number of Roma people and in other areas than the ones mentioned above.

The fact that they chose to settle in a very large number in the localities crossed by the great railway lines or the European roads, proves that the Roma people still kept in the character of the nomad device of their ancestors. The Roma migrants, in the present period, choose however the countries of the Western Europe [5] fact by which we can say that this contributes to economic development of the localities. 


\section{REFERENCES}

[1] Achim, V. (1998). Tiganii in istoria Romaniei, Bucuresti.

[2] Baron, N. (2015). Railways and demographic change, Edward Elgar Publishing, https://hal.archives-ouvertes.fr/hal-01310515, vol. 2, pp 22-37, 2015.

[3] Bălan, T. (1933). Documente bucovinene, Bucuresti, vol. 6, pp 321-324.

[4] Bogdan, I. (1913). Hrisoave si carti domnesti. Documentele lui Stefan cel Mare, Bucuresti, vol. 1, pp 22-37, 1913.

[5] Gălbău, I. \& Efros, V. \& Vasilcu, D., (2016). Migration between integration and discrimination. The case study of Roma communities of romanian nationality in the city of Rennes, France, Geobalcanica Proceeding, Macedonia, pp 215-221, DOI: http://dx.doi.org/10.18509/GBP.2016.29

[6] Marti-Hennenberg, J. (2013). European integration and national models for railway networks (1840-2010), Journal of Transport Geography, vol. 26, pp 126-138, http://dx.doi.org/10.1016/j.jtrangeo.2012.09.004.

[7] Mitchell, B.R. (1964) 'The Coming of the Railway and United Kingdom Economic Growth', The Journal of Economic History, 24(3), pp. 315-336. doi: $10.1017 /$ S0022050700060873. 